\title{
CHOLESTEROL AND CHLORIDE IN ACUTE HEART FAILURE
}

\author{
Bojana Radulović ${ }^{1}$, Ines Potočnjak ${ }^{2}$, Sanda Dokoza Terešak ${ }^{2}$, Matias Trbušić ${ }^{2,3}$, Nada Vrkić, \\ Azra Huršidić Radulović ${ }^{5}$, Neven Starčević ${ }^{6}$, Milan Milošević 7 , Vesna Degoricija ${ }^{2,3}$ and Saša Frank ${ }^{8}$ \\ ${ }^{1}$ Zagreb University Hospital Centre, Zagreb, Croatia; \\ ${ }^{2}$ Sestre milosrdnice University Hospital Centre, Zagreb, Croatia; \\ ${ }^{3}$ University of Zagreb School of Medicine, Zagreb, Croatia; \\ ${ }^{4}$ University of Zagreb Faculty of Pharmacy and Biochemistry, Zagreb, Croatia; \\ ${ }^{5}$ Occupational Medicine Office, Zagreb, Croatia; ${ }^{6}$ Sveti Duh University Hospital, Zagreb, Croatia; \\ ${ }^{7}$ Andrija Štampar School of Public Health, University of Zagreb School of Medicine, Zagreb, Croatia; \\ ${ }^{8}$ Institute of Molecular Biology and Biochemistry, Centre of Molecular Medicine, \\ Medical University of Graz, Graz, Austria
}

\begin{abstract}
SUMMARY - Detecting predictors of poor outcome is crucial for understanding the underlying pathophysiology of heart failure (HF) and thus creating new therapeutic concepts. It is well established that low serum lipid levels are associated with unfavorable outcomes in HF patients. Several studies examined the association between serum lipids and established predictors of mortality in HF patients. The aim of the present study was to examine the association of serum lipid and chloride concentrations, as well as their impact on survival in acute heart failure (AHF). The present study was performed as a prospective, single-centre, observational research. The study included 152 patients with AHF. Spearman's correlation coefficient revealed a significant positive correlation of serum chloride levels with serum levels of total cholesterol $(\rho 0.221, \mathrm{p}=0.006)$, low-density lipoprotein cholesterol $(\mathrm{LDL}-\mathrm{c})(\rho$ 0.187, $\mathrm{p}=0.015)$ and high-density lipoprotein-cholesterol (HDL-c) $(\rho 0.169, \mathrm{p}=0.038)$. Binary logistic regression revealed a significant association of chloride, total cholesterol and LDL-c serum levels measured at admission with hospital survival (OR 1.077, CI 1.01-1.154, $\mathrm{p}=0.034),(\mathrm{OR}$ 1.731, CI 1.090-2.748, $\mathrm{p}=0.020)$ and (OR 1.839, CI 1.033-3.274, $\mathrm{p}=0.038)$, respectively, as well as with 3-month survival (OR 1.065, CI 1.002-1.131, $\mathrm{p}=0.042$ ), (OR 1.625, CI 1.147-2.303, $\mathrm{p}=0.006$ ) and (OR 1.711, CI 1.117-2.622, $\mathrm{p}=0.014)$, respectively. In conclusion, positive statistical association between serum cholesterol (total cholesterol, LDL-c and HDL-c) and chloride levels may suggest their similar modulation by AHF pathophysiology. Serum levels of total cholesterol, LDL-c and chloride contribute to patient survival.
\end{abstract}

Key words: Heart failure; Cholesterol, LDL; Cholesterol, HDL; Lipids; Chloride

\section{Introduction}

Heart failure (HF) has been in the focus of interest of cardiovascular studies because of its high prevalence, wide spectrum of etiology and incomplete under-

Correspondence to: Bojana Radulović, $M D$, PhD, Zagreb University Hospital Centre, Kišpatićeva 12, HR-10000 Zagreb, Croatia E-mail: bojanara84@yahoo.com

Received November 19,2018, accepted December 20, 2018 standing of this syndrome. Due to unclear pathophysiology, researchers have directed their attention to discovering the underlying mechanism of HF. Studies have been focused mainly on detecting predictors of poor outcome and thus hypothesizing and creating new concepts of the underlying pathophysiology.

The connection between lipids and coronary artery disease has been acknowledged ${ }^{1}$. Nonetheless, the relationship between lipids and HF is yet to be clarified. 
Paradoxically, a well-known fact is that low serum levels of total cholesterol, low-density lipoprotein cholesterol (LDL-c), high-density lipoprotein cholesterol (HDL-c) and triglycerides have been associated with worse outcomes in HF studies. This phenomenon is part of the so-called reverse epidemiology in HF, whereby the risk factors of poor clinical outcome and mortality in the general population, such as obesity, hypercholesterolemia, and high blood pressure, have been associated with better survival ${ }^{2-10}$. As a result of those studies, the level of total cholesterol has become part of the predictive models for HF survival such as the Seattle Heart Failure Model ${ }^{11}$. Several studies investigated the connection between serum lipid levels with previously established predictors of outcome in HF patients, aiming at elucidating the pathophysiology of lipids in HF. However, no study so far has explored the association of serum lipid and chloride levels.

Hyponatremia is also considered to have a predictive value for survival in HF patients. Nevertheless, studies in the past years showed that serum chloride levels were independently and inversely associated with mortality in HF patients and that chloride could predict development of hyponatremia in these patients, thus making chloride the main electrolyte for predicting outcome in $\mathrm{HF}$ patients ${ }^{12-14}$. The pathophysiology of hypochloremia in HF is still unknown. Exploration of the association between serum lipid and chloride levels could generate new knowledge concerning HF pathophysiology. Therefore, the present study investigated the association between serum chloride and lipid levels and their impact on survival in acute heart failure (AHF) patients.

\section{Patients and Methods}

\section{Study design and patients}

The study was a prospective, single-centre, observational research conducted over 16 months and concluded at the beginning of 2015. It included 152 consecutive adults hospitalized for AHF through Emergency Department, Sestre milosrdnice University Hospital Centre. The study was designed and conducted in accordance with the principles of the Declaration of Helsinki and approved by the hospital Ethics Committee ${ }^{15}$. A written informed consent was obtained from the patients. Inclusion required patients older than 18 years with a primary diagnosis of AHF, which was confirmed within 24 hours of admission by $\mathrm{N}$ terminal pro-brain natriuretic peptide (NT-proBNP) values and echocardiography. The patients were categorized by clinical presentation of $\mathrm{HF}$ and ejection fraction $(\mathrm{EF})^{16-18}$.

\section{Data collection}

At first encounter in emergency department, sociodemographic status, past medical history, signs and symptoms, as well as chest radiography and electrocardiography were obtained in each patient. Echocardiography was performed on the first day post admission. Blood samples were obtained from medial cubital vein for routine laboratory assays at admission (complete blood count, metabolic and electrolyte panel, blood urea nitrogen, creatinine, lipid profile, and NTproBNP). Standard serum electrolytes, renal panel and serum lipids were tested on Beckman Coulter instrument AU 2700, 2007 (Brea, CA, US) and Architect c8000, Abbott 2013 (Chicago, IL, US). Elecsys e411 (Roche Diagnostics GmbH, Mannheim, Germany) measured the level of Nt-proBNP. Admission chloride, total plasma cholesterol, LDL-c, HDL-c and triglycerides were defined as values obtained on presentation at emergency department. Hypochloremia was defined as serum concentration of chloride lower than $98 \mathrm{mmol} / \mathrm{L}$. Total cholesterol lower than $5 \mathrm{mmol} / \mathrm{L}$ was considered normal, and so was the value of LDL-c lower than $3 \mathrm{mmol} / \mathrm{L}$. HDL-c concentration higher than $1.2 \mathrm{mmol} / \mathrm{L}$ in women and higher than 1.00 $\mathrm{mmol} / \mathrm{L}$ in men was set as normal. Serum concentration of triglycerides higher than $1.7 \mathrm{mmol} / \mathrm{L}$ was a high value.

All data were recorded on days 2, 3 and 7 of hospital stay, and follow up measurements were performed at three months.

\section{Statistical analysis}

The MedCalc ${ }^{\text {TM }}$ v. 15.1 (MedCalc Software, Belgium) software was used for statistical assessment. Kolmogorov-Smirnov test determined the distribution of quantitative data. After determination, nonparametric or parametric statistical tests were utilized as appropriate. The median and interquartile ranges were used to display interquartile ranges. Absolute fre- 
Table 1. Baseline characteristics of patients $(N=152)$

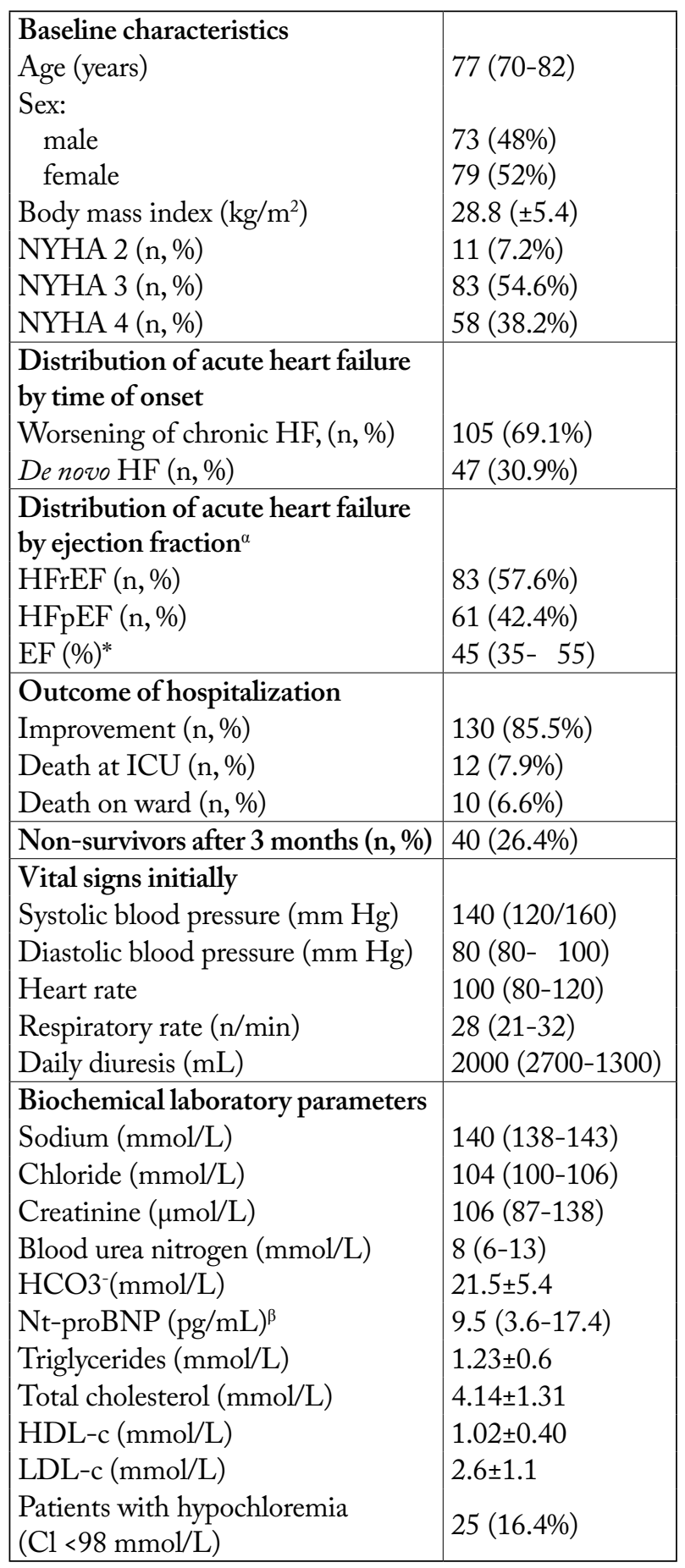

$\mathrm{HFpEF}=$ heart failure with preserved ejection fraction; $\mathrm{HFrEF}=$ heart failure with reduced ejection fraction; ICU = intensive care unit; NYHA = New York Heart Association functional classification; Nt-proBNP(pg/mL) = N-terminal pro-brain natriuretic peptide; $\mathrm{EF}=$ ejection fraction; LDL-c = low-density lipoprotein cholesterol; HDL-c = high-density lipoprotein cholesterol; ${ }^{\alpha} 144$ patients included; ${ }^{\beta} 147$ patients included
Table 2. Correlation of serum sodium and chloride levels with serum lipid levels at admission

\begin{tabular}{|l|l|l|}
\hline Variable & & Sodium $(\mathrm{mmol} / \mathrm{L})$ \\
\hline Chloride $(\mathrm{mmol} / \mathrm{L})$ & $\rho$ & 0.743 \\
& $\mathrm{p}$ & $<0.001$ \\
\hline Total cholesterol $(\mathrm{mmol} / \mathrm{L})$ & $\rho$ & 0.071 \\
& $\mathrm{p}$ & 0.387 \\
\hline LDL-c $(\mathrm{mmol} / \mathrm{L})$ & $\rho$ & 0.019 \\
& $\mathrm{p}$ & 0.819 \\
\hline HDL-c $(\mathrm{mmol} / \mathrm{L})$ & $\rho$ & 0.106 \\
& $\mathrm{p}$ & 0.195 \\
\hline Triglycerides $(\mathrm{mmol} / \mathrm{L})$ & $\rho$ & 0.057 \\
& $\mathrm{p}$ & 0.489 \\
\hline
\end{tabular}

Spearman's coefficient of rank correlation was used in calculation; LDL-c = low-density lipoprotein cholesterol; HDL-c = high-density lipoprotein cholesterol; $\rho=$ correlation coefficient; $p=$ calculated probability

quencies were used for categorical variables. Spearman correlation coefficients were calculated to assess the correlation of serum chloride and lipid levels. Binary logistic regression analysis was performed to study the impact of chloride, lipids, statin treatment and $\mathrm{EF}$ on hospital and 3-month mortality. The level of statistical significance was set at $\mathrm{p}<0.05$.

\section{Results}

A total of 152 patients were included in the study conducted during a 16-month period. Most of the patients had a positive past medical history of hypertension (89.5\%), metabolic syndrome (55.9\%) and type 2 diabetes mellitus (51.7\%). Twenty-five (16.5\%) patients had hypochloremia $(\mathrm{Cl}<98 \mathrm{mmol} / \mathrm{L})$ at admission. Hospital mortality was $14.5 \%(\mathrm{n}=22)$ and after 3 -month follow up, mortality was $27.4 \%(\mathrm{n}=40)$. $\mathrm{Pa}$ tient general information is shown in Table 1.

As shown in Figure 1, serum chloride levels were significantly correlated with serum levels of total cholesterol (Fig. 1A), LDL-c (Fig. 1B) and HDL-c (Fig. 1C), but not with serum triglyceride levels (Fig. 1D).

Interestingly, in contrast to chloride, serum sodium levels correlated significantly with chloride levels but not with serum lipid levels (Table 2).

As revealed by binary logistic regression analyses, the levels of serum chloride, total cholesterol and LDL-c measured on the first day of hospitalization 

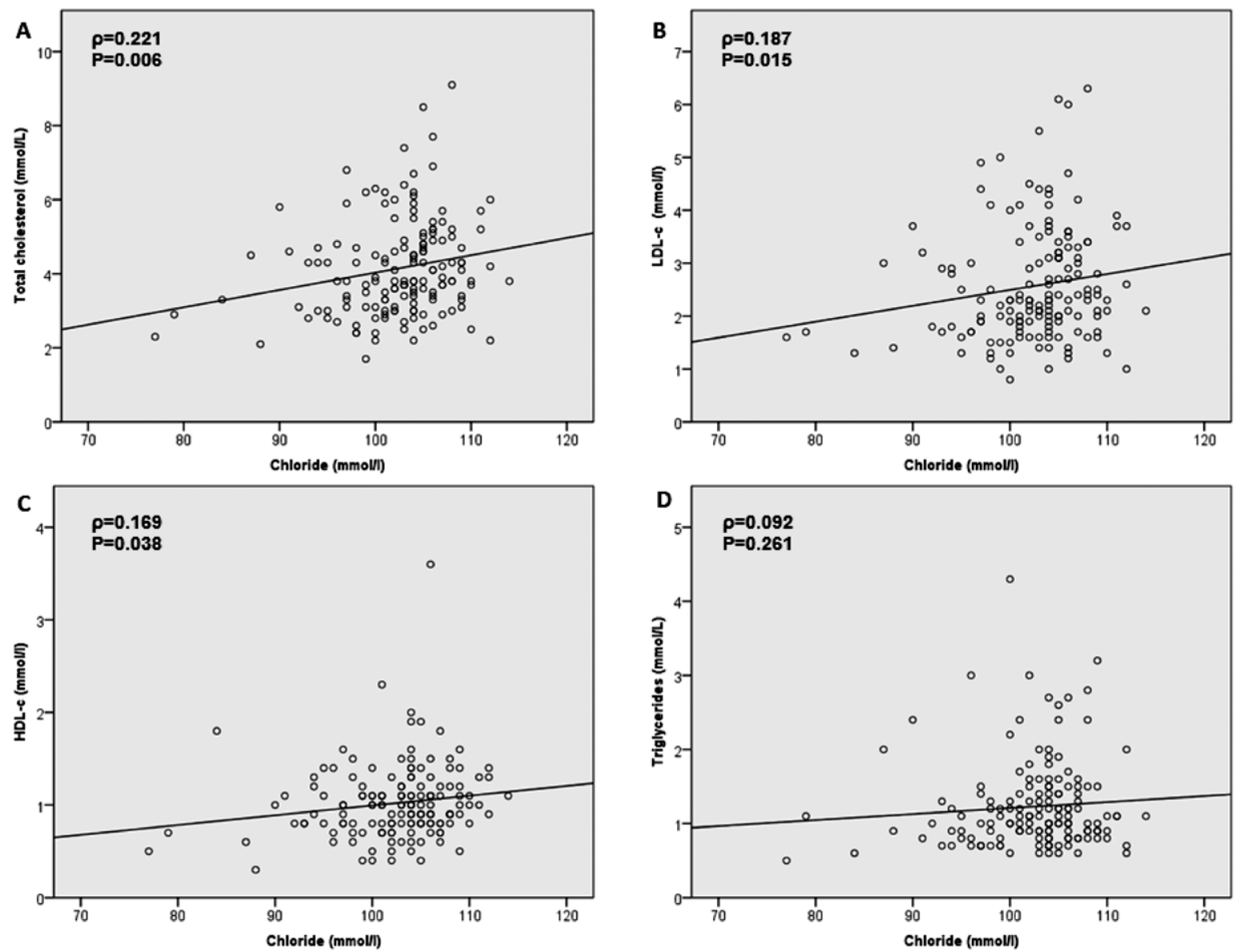

Fig. 1. Correlation of serum chloride with various lipid levels.

Correlation of serum chloride and (A) total cholesterol; (B) LDL-c; (C) HDL-c; and (D) triglyceride levels was calculated using Spearman's correlation coefficients; $\rho=$ correlation coefficient; LDL-c $=$ low-density lipoprotein cholesterol; HDL-c $=$ high-density lipoprotein cholesterol

showed a significant positive association with both hospital and 3-month survival of AHF patients (Table 3). No association was found for serum HDL-c and triglycerides (Table 3), or for statin therapy before hospitalization and EF (not shown).

Multiple logistic regression models were made with serum sodium, chloride and cholesterol levels, therapy and outcome. Although they were significant and explained more than $60 \%$ of variance, only the association of total cholesterol and in-hospital survival remained significant (Table 4).

\section{Discussion}

In the present study, we found a statistical positive correlation between serum cholesterol and chloride concentrations. Additionally, we found that patients with higher serum cholesterol levels had higher both hospital and 3-month survival. Similar was found for serum chloride levels, namely, patients with higher serum chloride levels had higher both hospital and 3month survival. Numerous studies in the last ten years revealed higher mortality in HF patients with lower total cholesterol levels ${ }^{6-8}$. In contrast, only few studies acknowledged low serum chloride levels as a predictor of poor outcome in HF patients ${ }^{12-14}$. To our knowledge, no study so far has addressed the association of serum chloride and cholesterol levels in AHF. The relationship between serum chloride and cholesterol concentrations in AHF might suggest a similar mode of their regulation by AHF pathophysiology. This new knowledge might help getting better insight into the 
Table 3. Binary logistic regression analysis of laboratory parameters, and in-hospital and 3-month survival

\begin{tabular}{|c|c|c|c|c|c|c|c|c|}
\hline \multirow{3}{*}{ Variable } & \multicolumn{4}{|c|}{ In-hospital survival } & \multicolumn{4}{|c|}{ 3-month follow up survival } \\
\hline & \multirow{2}{*}{ OR } & \multicolumn{2}{|c|}{$95 \% \mathrm{CI}$} & \multirow{2}{*}{$\mathrm{p}$ value } & \multirow{2}{*}{ OR } & \multicolumn{2}{|c|}{$95 \% \mathrm{CI}$} & \multirow{2}{*}{$\mathrm{p}$ value } \\
\hline & & lower & upper & & & lower & upper & \\
\hline Chloride $(\mathrm{mmol} / \mathrm{L})$ & 1.077 & 1.010 & 1.154 & 0.034 & 1.065 & 1.002 & 1.131 & 0.042 \\
\hline Total cholesterol $(\mathrm{mmol} / \mathrm{L})$ & 1.731 & 1.090 & 2.748 & 0.020 & 1.625 & 1.147 & 2.303 & 0.006 \\
\hline $\mathrm{LDL}-\mathrm{c}(\mathrm{mmol} / \mathrm{L})$ & 1.839 & 1.033 & 3.274 & 0.038 & 1.711 & 1.117 & 2.622 & 0.014 \\
\hline $\mathrm{HDL}-\mathrm{c}(\mathrm{mmol} / \mathrm{L})$ & 2.563 & 0.596 & 11.022 & 0.206 & 2.410 & 0.775 & 7.491 & 0.129 \\
\hline Triglycerides $(\mathrm{mmol} / \mathrm{L})$ & 1.830 & 0.682 & 4.914 & 0.230 & 1.658 & 0.809 & 3.398 & 0.167 \\
\hline
\end{tabular}

$\mathrm{OR}$ = odds ratio; $\mathrm{CI}=$ confidence interval; LDL-c = low-density lipoprotein cholesterol; HDL-c = high-density lipoprotein cholesterol; significant associations depicted in bold

Table 4. Multivariate logistic regression analysis of in-hospital and 3-month survival according to serum chloride and total cholesterol levels

\begin{tabular}{|c|c|c|c|c|c|c|c|c|c|c|}
\hline \multirow{3}{*}{ Variable } & \multicolumn{5}{|c|}{ In-hospital survival } & \multicolumn{5}{|c|}{ 3-month follow up survival } \\
\hline & \multirow{2}{*}{ OR } & \multicolumn{2}{|c|}{$95 \% \mathrm{CI}$} & \multirow[b]{2}{*}{$\mathrm{p}$} & \multirow{2}{*}{ Events } & \multirow{2}{*}{ OR } & \multicolumn{2}{|c|}{$95 \% \mathrm{CI}$} & \multirow[b]{2}{*}{$\mathrm{p}$} & \multirow{2}{*}{ Events } \\
\hline & & lower & upper & & & & lower & upper & & \\
\hline Chloride $(\mathrm{mmol} / \mathrm{L})$ & 1.046 & 0.928 & 1.179 & 0.459 & 2215 & 1.016 & 0.919 & 1.123 & 0.508 & 5 \\
\hline Total cholesterol $(\mathrm{mmol} / \mathrm{L})$ & 1.680 & 1.020 & 2.770 & 0.041 & 221102 & 1.400 & 0.957 & 2.049 & 0.742 & J \\
\hline
\end{tabular}

The model was adjusted for age, serum sodium and statin therapy; $\mathrm{CI}=$ confidence interval; Events = number of events/number of patients; $\mathrm{OR}=$ odds ratio

pathophysiological mechanisms that determine the outcome in AHF.

There are several theories regarding the connection of low serum lipid levels and poor outcome in HF. According to one of these theories, low cholesterol levels are associated with a decreased ability of serum to cope with endotoxins, resulting in an increased inflammatory response in HF patients ${ }^{19}$. There are also several theories trying to explain low lipid levels in HF. The majority of these theories are based on the assumption that decreased calorie intake and impaired intestinal nutrient absorption might cause low lipid levels in a state of increased resting energy consumption ${ }^{20-22}$. Some recent studies implicated venous congestion and thereby associated reduced overall intestinal absorption, including that of dietary lipids, being an underlying mechanism for low serum lipid levels in $\mathrm{HF}^{23}$. Indeed, an inverse relationship between serum lipid levels and right ventricle end diastolic diameter (an indicator of the chronic volume overload status in HF) argues for the role of venous congestion in lowering serum lipids in $\mathrm{HF}^{23}$. However, it is unclear why serum chloride and not serum sodium levels are associated with serum cholesterol levels, knowing that the intake of both sodium and chloride is equally affected in bowel edema.

The positive statistical correlation between serum cholesterol and chloride levels found in the present study suggests that there might be similar pathophysiological mechanisms that modulate their levels in AHF. Accordingly, decreased total cholesterol, LDL-c and HDL-c levels might be governed by the mechanisms implicated in the pathophysiology of chloride disorders in HF. It has been established that WNK signaling is involved in chloride sensing, regulation of renin-angiotensin-aldosterone system, sodium transport, hypertension and regulation of diuretic activity ${ }^{24-27}$. Given the critical role of chloride in a number of important regulatory systems, one cannot exclude its role in the regulation of cholesterol homeostasis in AHF. Further investigation in a greater number of $\mathrm{pa}^{-}$ tients would be interesting ${ }^{28}$.

\section{Study strengths and limitations}

The study had a uniform and structured algorithm and protocol for hospitalized AHF patients and extensive data collection with pre-planned goals. The study topic is new, as it has never been considered or 
investigated. Nevertheless, the number of patients enrolled in the study was small. The study could not establish whether low cholesterol or low chloride was the cause or merely marker of AHF pathophysiology.

\section{Conclusion}

Positive statistical association between serum cholesterol (total cholesterol, LDL-c and HDL-c) and chloride levels might suggest their similar modulation by AHF pathophysiology. Serum levels of total cholesterol, LDL-c and chloride contribute to survival in AHF patients. Further larger studies are needed to confirm and elaborate our findings.

\section{Acknowledgment}

This work was supported by the Austrian Science Fund (P27166-B23 to S.F.) and the Jubilee Foundation of the Austrian National Bank (15858 to S.F.).

\section{References}

1. Ross R. Atherosclerosis - an inflammatory disease. N Engl J Med.1999;340:115-26. doi:10.1056/NEJM199901143400207

2. Rauchhaus M, Clark AL, Doehner W, Davos C, Bolger A, Sharma $\mathrm{R}$, et al. The relationship between cholesterol and survival in patients with chronic heart failure. J Am Coll Cardiol. 2003;42:1933-40. doi: 10.1016/S0140-6736(00)02690-8

3. Christ M, Klima T, Grimm W, Mueller H-H, Maisch B. Prognostic significance of serum cholesterol levels in patients with idiopathic dilated cardiomyopathy. Eur Heart J. 2006;27:691-9. doi: 10.1371/journal.pmed.0030333

4. Fonarow GC, Horwich TB. Cholesterol and mortality in heart failure: the bad gone good? J Am Coll Cardiol. 2003;42: 1941-3. doi: 0.1016/j.jacc.2003.09.005

5. Kahn MR, Kosmas CE, Wagman G, Serrao GW, Fallahi A, Grady KM, et al. Low-density lipoprotein levels in patients with acute heart failure. Congest Heart Fail. 2013;19:85-91. doi: $10.1111 / \mathrm{chf} .12006$

6. Charach G, George J, Roth A, Rogowski O, Wexler D, Sheps $\mathrm{D}$, et al. Baseline low-density lipoprotein cholesterol levels and outcome in patients with heart failure. Am J Cardiol. 2010; 105:100-4. doi: 10.1016/j.amjcard.2009.08.660

7. Mehra MR, Uber PA, Lavie CJ, Milani R V, Park MH, Ventura HO. High-density lipoprotein cholesterol levels and prognosis in advanced heart failure. J Heart Lung Transplant. 2009;28:876-80. doi: 10.1016/j.healun.2009.04.026

8. Kalantar-Zadeh K, Block G, Horwich T, Fonarow GC. Reverse epidemiology of conventional cardiovascular risk factors in patients with chronic heart failure. J Am Coll Cardiol. 2004; 43:1439-44. doi: 10.1016/j.jacc.2003.11.039
9. Lavie CJ, Mehra MR, Milani R V. Obesity and heart failure prognosis: paradox or reverse epidemiology? Eur Heart J. 2005; 26:5-7. doi: 10.1093/eurheartj/ehi055

10. Potočnjak I, Degoricija $V$, Trbušić $M$, Terešak SD, Radulović $B$, Pregartner G, et al. Metrics of high-density lipoprotein function and hospital mortality in acute heart failure patients. PLoS One. 2016;11:e0157507. doi: 10.1371/journal.pone.0157507

11. Levy WC, Mozaffarian D, Linker DT, Sutradhar SC, Anker SD, Cropp AB, et al. The Seattle Heart Failure Model: Prediction of survival in heart failure. Circulation. 2006;113:1424-33. doi: 10.1161/CIRCULATIONAHA.105.584102

12. Testani JM, Hanberg JS, Arroyo JP, Brisco MA, Ter Maaten JM, Wilson FP, Bellumkonda L, Jacoby D, Tang WH, Parikh CR. Hypochloraemia is strongly and independently associated with mortality in patients with chronic heart failure. Eur J Heart Fail. 2016;18:660-8. doi: 10.1002/ejhf.477

13. Grodin JL, Simon J, Hachamovitch R, Wu Y, Jackson G, Halkar M, et al. Prognostic role of serum chloride levels in acute decompensated heart failure. J Am Coll Cardiol. 2015; 66:659-66. doi: 10.1016/j.jacc.2015.06.007

14. Radulovic B, Potocnjak I, Teresak SD, Trbusic M, Vrkic N, Malogorski D, et al. Hypochloraemia as a predictor of developing hyponatraemia and poor outcome in acute heart failure patients. Int J Cardiol. 2016;212:237-41. doi: 10.1016/j.ijcard.2016.03.081

15. World Medical Association. World Medical Association Declaration of Helsinki Ethical Principles for Medical Research Involving Human Subjects. JAMA. 310:2191-4. doi: 10.1001/ jama.2013.281053

16. McMurray JJV, Adamopoulos S, Anker SD, et al. ESC Guidelines for the diagnosis and treatment of acute and chronic heart failure 2012: The Task Force for the Diagnosis and Treatment of Acute and Chronic Heart Failure 2012 of the European Society of Cardiology. Developed in collaboration with the Heart Failure Association (HFA) of the ESC. Eur Heart J. 2012; 33:1787-847. doi: 10.1093/eurjhf/hfs105

17. Dickstein K, Cohen-Solal A, Filippatos G, McMurray JJ, Ponikowski P, Poole-Wilson PA, et al. ESC guidelines for the diagnosis and treatment of acute and chronic heart failure 2008: the Task Force for the Diagnosis and Treatment of Acute and Chronic Heart Failure 2008 of the European Society of Cardiology. Developed in collaboration with the Heart Failure Association of the ESC (HFA) and endorsed by the European Society of Intensive Care Medicine (ESICM). Euro Heart J Fail. 2008;10:933-89. doi: 10.1016/j.ejheart.2008.08.005

18. Yancy CW, Jessup M, Bozkurt B, Butler J, Casey DE, Jr., Drazner MH, et al. 2013 ACCF/AHA guideline for the management of heart failure: a report of the American College of Cardiology Foundation/American Heart Association Task Force on Practice Guidelines. J Am Coll Cardiol. 2013;62: e147-239. doi: 10.1016/j.jacc.2013.05.019

19. Rauchhaus M, Coats AJ, Anker SD. The endotoxin-lipoprotein hypothesis. Lancet. 2000;356:930-3. doi: 10.1016/j.jacc. 2003.07.016 
20. Berry C, Clark AL. Catabolism in chronic heart failure. Eur Heart J. 2000;21:521-32. doi: 10.1053/euhj.1999.188

21. Jacobsson A, Pihl-Lindgren E, Fridlund B. Malnutrition in patients suffering from chronic heart failure; the nurse's care. Eur J Heart Fail J Work Gr Hear Fail Eur Soc Cardiol. 2001;3: 449-56. doi: 10.1016/S1388-9842(01)00139-8

22. Velavan P, Huan Loh P, Clark A, Cleland JGF. The cholesterol paradox in heart failure. Congest Heart Fail. 2007;13:336-41. doi: 10.1111/j.1527-5299.2007.07211.x

23. Chen Y, He X, Meng H, Zhao Q, Zhen Y, Tian L, et al. Relationship between lipid levels and right ventricular volume overload in congestive heart failure. J Geriatr Cardiol. 2014;11: 192-9. doi: 10.11909/j.issn.1671-5411.2014.03.011

24. Susa K, Sohara E, Isobe K, Chiga M, Rai T, Sasaki S, et al. WNK-OSR1/SPAK-NCC signal cascade has circadian rhythm dependent on aldosterone. Biochem Biophys Res Commun. 2012;427:743-7. doi: 10.1016/j.bbrc.2012.09.130
25. Roy A, Al-Qusairi L, Donnelly BF, Ronzaud C, Marciszyn AL, Gong F, et al. Alternatively spliced proline-rich cassettes link WNK1 to aldosterone action. J Clin Invest. 2015;125: 3433-48. doi: 10.1172/JCI75245

26. Terker AS, Zhang C, Erspamer KJ, Gamba G, Yang C-L, E1lison $\mathrm{DH}$. Unique chloride-sensing properties of WNK4 permit the distal nephron to modulate potassium homeostasis. Kidney Int. 2016;89:127-34. doi: 10.1038/ki.2015.289

27. Hoorn EJ, Van Der Lubbe N, Zietse R. The renal WNK kinase pathway: a new link to hypertension. Nephrol Dial Transplant. 2009;24:1074-7. doi: 10.1093/ndt/gfp013

28. Potočnjak I, Bodrožić-Džakić T, Šmit I, Trbušić M, Milošević M, Degoricija V. Gender-associated differences in acute heart failure patients presenting to emergency department. Acta Clin Croat. 2015 Sep;54(3):257-65.

Sažetak

\title{
KOLESTEROL I KLORIDI U AKUTNOM ZATAJIVANJU SRCA
}

\author{
B. Radulović, I. Potočnjak, S. Dokoza Terěsak, M. Trbušić, N. Vrkić, A. Huršidić Radulović, N. Starčević, \\ M. Miloševic, V. Degoricija i S. Frank
}

Otkrivanje pokazatelja lošijeg ishoda u bolesnika s akutnim zatajivanjem srca je od velike važnosti za razumijevanje njegove patofiziologije, a time i za otkrivanje novih terapijskih pristupa. Poznato je da su niske koncentracije lipida u serumu povezane s lošijim ishodom u bolesnika s akutnim zatajivanjem srca. Brojne studije su pokušale utvrditi vezu između koncentracije lipida u serumu i ostalih prediktora lošijeg ishoda u bolesnika s akutnim zatajivanjem srca. Cilj istraživanja bio je istražiti povezanost koncentracije lipida i klorida u serumu kod bolesnika sa zatajivanjem srca te njihov utjecaj na preživljenje. Studija je provedena u obliku prospektivnog opservacijskog istraživanja u jednom bolničkom centru. $U$ istraživanje je bilo uključeno 157 bolesnika s akutnim zatajivanjem srca. Spearmanovi koeficijenti korelacije su pokazali značajnu pozitivnu povezanost koncentracije klorida i ukupnog kolesterola ( $\rho$ 0,221, p=0,006), lipoproteina male gustoće (LDL-c) ( $\rho$ 0,187, $\mathrm{p}=0,015)$ i lipoproteina velike gustoće (HDL-c) $(\rho 0,169, \mathrm{p}=0,038)$. Binarnom logističkom regresijom je uočena statistički značajna povezanost koncentracije klorida, ukupnog kolesterola i LDL-c u bolesnika s akutnim zatajivanjem srca prilikom prijma bolesnika u bolnicu i unutarbolničkog preživljenja (OR 1,077, CI 1,01-1,154, p=0,034), (OR 1,731, CI 1,090-2,748, $\mathrm{p}=0,020)$ i (OR 1,839, CI 1,033-3,274, p=0,038), kao i preživljenja nakon tri mjeseca (OR 1,065, CI 1,002-1,131, p=0,042), (OR 1,625, CI 1,147-2,303, p=0,006) i (OR 1,711, CI 1,117-2,622, p=0,014). Zaključno, pozitivna statistička povezanost između koncentracije kolesterola u serumu (ukupni kolesterol, LDL-c i HDL-c) i koncentracije klorida može ukazivati na njihovu sličnu ulogu u patofiziologiji akutnog zatajivanja srca. Koncentracija ukupnog kolesterola, LDL-c i klorida u serumu sudjeluju u preživljenju bolesnika.

Ključne riječi: Srčano zatajivanje; LDL-kolesterol; HDL-kolesterol; Lipidi; Klorid 